Www.jmscr.igmpublication.org

Index Copernicus Value: 79.54

ISSN (e)-2347-176x ISSN (p) 2455-0450

crossref DOI: https://dx.doi.org/10.18535/jmscr/v7i5.84

\title{
A Histopathological Spectrum of Ovarian Lesions: As Studied in RIMS- A Tertiary Care Hospital in Jharkhand
}

\author{
Authors \\ Dr Ramesh Kumar Srivastava ${ }^{1}$, Dr Doyel Halder ${ }^{2 *}$, Dr Nidhi PA Barla ${ }^{3}$ \\ ${ }^{1}$ Professor and Head, Department of Pathology, RIMS, Ranchi, Jharkhand, India \\ ${ }^{2,3}$ Junior Resident, Department of Pathology, RIMS, Ranchi, Jharkhand, India \\ *Corresponding Author \\ Dr Doyel Halder \\ Junior Resident, Department of Pathology, RIMS, Ranchi, Jharkhand, India
}

\begin{abstract}
Aim: The aim of this study is to highlight the histopathological spectrum of ovarian both benign and malignant and to compare our study with findings of other centers.

Materials and Methods: Hematoxylin and eosin stained slides of ovarian biopsies diagnosed at Rajendra Institute of Medical Sciences, Ranchi, Jharkhand for 3 years (January 2016 to December 2018 ) were archived, scrutinized, and studied. Clinical biodata and diagnosis were obtained from the Histopathology section.

Results: A total of 1091 ovarian biopsies were reviewed. Of this, 556 (50.96\%) were nonneoplastic. Again 339 (31.08\%) were benign neoplastic tumours and 196 (17.96\%) were malignant tumours. Out of the 556 nonneoplastic (functional cysts) lesions, follicular cyst was the most commonly encountered, constituting 160 cases (28.78\%). The peaks age incidence for nonneoplastic and benign neoplastic lesions occurred in the $3^{\text {rd }}$ decade. Two peaks age incidence was noted for malignant tumors $-5^{\text {th }}$ and $7^{\text {th }}$ decades. Germ cell tumor constituted the most common neoplastic ovarian tumour $(n=113 ; 57.65 \%)$ diagnosed.

Conclusion: Functional ovarian cysts were the most commonly encountered ovarian lesions in our study population. The most common variety of functional cyst were follicular cyst and corpus luteum cyst with majority occurring in the reproductive age groups. Among the ovarian tumors, germ cell tumors followed by surface epithelial tumours were most commonly seen.

Keywords: Follicular cyst, luteal cysts, germ cell tumour, surface epithelial tumour.
\end{abstract}

\section{Introduction}

Ovarian masses consist of functional and pathological lesions. Functional lesions are mainly cystic and are the most commonly encountered lesions of this retroperitoneal organ. ${ }^{[1]}$ Majority of the functional cysts are simple cysts, while minority consists of complex cystic architecture. Studies have shown that $90 \%$ of these cysts are resolved spontaneously. ${ }^{[2]}$ These cyst are frequently seen in young female in their 2nd decades due to failure of ovulation. However, fewer cases could also be seen in perimenopausal and postmenopausal women. ${ }^{[2,3]}$ Pathological lesions are predominantly tumours which could be benign, borderline, and malignant. Generally speaking, these tumors are rarer in childhood and adolescent age groups as studies have confirmed that only about $2 \%$ of ovarian tumours are seen in 
children. ${ }^{[2,3]}$ Most benign lesions of the ovary occur in childbearing age groups and are often cystic, while malignant tumours are more common in the elderly women. ${ }^{[4]}$

Globally, ovarian malignancy constitutes about $23 \%$ of all gynecological tumours with the highest fatality cases of incidence rate. ${ }^{[5,6]}$ In developing countries including India, there are low epidemiological statistics of ovarian cancers because most cases are underreported, in spite of the fact that it constitutes one of the most common gynecological problems locally and globally. There are considerable variation in the incidence of ovarian cancer across the countries with the highest rates in industrialised western nations and lowest rate in developing countries. In India, inspite of the low incidence, there is a steady increase in age standardised prevalence of ovarian cancer by $3 \%$ per year in different state registries over a period of time. In most of the population based cancer registries in India, ovarian cancer remains the third leading cause of cancer among women. The age adjusted incidence rates of ovarian cancer varies between 5.4 and 8.0 per one lakh in different parts of country.

The aim of this study is to evaluate the histopathological patterns of ovarian lesions both benign and malignant in a tertiary care centre of Jharkhand, an eastern state of India and to compare our study with findings of other researchers across the world.

\section{Material and Method}

It was a three year study done retrospectively from January 2016 to December 2018. It was done in the histopathology section of Department of Pathology of Rajendra Institute of Medical Sciences (RIMS), Ranchi. Retrospective analysis of all ovary specimens received in the department was done. All histopathological data pertaining to those specimens maintained in the histopathology section was retrieved and reviewed. Histology slides of all such cases were reviewed. Staining was done with Haematoxylin and Eosin stains. Each case was analysed with respect to age, clinical presentation and microscopic diagnosis. Ovarian carcinoma were classified using World Health Organisation (WHO) histological classification (2014).

\section{Observation}

556 i.e. ( $50.96 \%$ ) of non-neoplastic (functional cysts), $339(31.08 \%)$ benign neoplastic tumors and 196 ( $17.96 \%$ ) malignant tumours giving a totality of 1091 ovarian biopsies were reviewed at Rajendra Institute of Medical Sciences ( RIMS ), Ranchi. Out of the 556 non-neoplastic lesions, follicular cyst was the most commonly encountered lesion accounting for 160 cases (28.78\%). This was followed by corpus luteum cyst which accounted 142 cases (25.54 \%) and haemorrhagic cyst which consisted of 137 cases (24.65\%). Others included simple/serous cyst constituting 60 cases $(10.79 \%)$. Other less common non-neoplastic lesions were tubo-ovarian cyst and multicystic/ polycystic disease accounting for 20 cases (3.59\%) and 37 cases (6.65\%), respectively. (Table 1$)$

Table 1: Frequency and pattern of functional ovarian cysts

\begin{tabular}{|l|c|c|}
\hline Type of cyst & $\begin{array}{c}\text { Total number } \\
\text { of cases }(\mathbf{n})\end{array}$ & $\begin{array}{c}\text { Frequency } \\
(\boldsymbol{\%})\end{array}$ \\
\hline Corpus luteum cyst & 142 & 25.54 \\
\hline Haemorrhagic cyst & 137 & 24.65 \\
\hline Follicular cyst & 160 & 28.78 \\
\hline Simple/ Serous Cyst & 60 & 10.79 \\
\hline Tubo-ovarian cyst & 20 & 3.59 \\
\hline Multicystic/ Polycystic & 37 & 6.65 \\
\hline
\end{tabular}

Table 2 illustrates that $3^{\text {rd }}$ decade was the most common peak age of incidence for non-neoplastic lesions $(\mathrm{n}=251 ; 45.15 \%)$ followed by $4^{\text {th }}$ decade $(\mathrm{n}=111 ; 19.97 \%)$. Benign neoplastic lesions also showed similar peak age of incidence, with $3^{\text {rd }}$ decade being most common $(\mathrm{n}=109 ; 30.09 \%)$ followed by $4^{\text {th }}$ decade $(n=81 ; 20.89 \%)$ which was $2^{\text {nd }}$ most common. Two peak ages $\left(5^{\text {th }}\right.$ and $7^{\text {th }}$ decade) was noted for malignant tumours. $7^{\text {th }}$ decade was most common with peak incidence of $(\mathrm{n}=39,40.69 \%)$ followed by $5^{\text {th }}$ decade $(\mathrm{n}=30$, $30.28 \%$ ). 
Table 2: Age distribution and Frequency of ovarian lesions

\begin{tabular}{|l|c|c|c|}
\hline $\begin{array}{l}\text { Age group } \\
\text { (years })\end{array}$ & $\begin{array}{c}\text { Non- } \\
\text { neoplastic } \\
\text { Lesion ( } \mathbf{n} \text { ) }\end{array}$ & $\begin{array}{c}\text { Benign } \\
\text { Neoplastic } \\
\text { Lesion (n ) }\end{array}$ & $\begin{array}{c}\text { Malignant } \\
\text { Neoplastic } \\
\text { Lesion(n) }\end{array}$ \\
\hline $10-19$ & 56 & 31 & 2 \\
\hline $20-29$ & 25 & 102 & 4 \\
\hline $30-39$ & 111 & 81 & 3 \\
\hline $40-49$ & 77 & 68 & 30 \\
\hline $50-59$ & 28 & 10 & 8 \\
\hline $60-69$ & 33 & 24 & 39 \\
\hline $70-79$ & 0 & 17 & 5 \\
\hline $80+$ & 0 & 6 & 5 \\
\hline
\end{tabular}

Table 3 shows classification of ovarian tumours according to the WHO classification of these tumours and Table 4 shows the age distribution. The most common tumour among them was germ cell tumour consisting of 113 cases (57.65\%) with peak age of incidence at the $3^{\text {rd }}$ decade $(n=$ $55 ; 48.68 \%$ ). This was followed by surface epithelial tumours accounting for 56 cases (29.60 $\%$ ) with peak age of incidence in the $4^{\text {th }}$ decade of life accounting for 17 cases $(29.32 \%)$. Sex cord stromal tumour constituted 21 cases $(10.71 \%)$ with peak age of incidence in the $4^{\text {th }}$ decade $(\mathrm{n}=$ $9,42.86 \%$ ), while metastatic tumours of the ovary were relatively rare constituting only 4 cases $(2.04$ $\%$ ) with 2 cases in $7^{\text {th }}$ decade of life and 1 case each in $8^{\text {th }}$ and $9^{\text {th }}$ decade.

Table 3: Frequency of different malignant ovarian tumours

\begin{tabular}{|l|c|c|}
\hline Type & $\begin{array}{c}\text { Total number of } \\
\text { cases } \mathbf{( n )}\end{array}$ & $\begin{array}{c}\text { Frequency } \\
(\mathbf{\%})\end{array}$ \\
\hline Germ cell tumour & 113 & 57.65 \\
\hline $\begin{array}{l}\text { Surface epithelial } \\
\text { tumours }\end{array}$ & 58 & 29.60 \\
\hline Sex cord stromal tumours & 21 & 10.71 \\
\hline Metastatic tumours & 4 & 2.04 \\
\hline
\end{tabular}

Table 4: Age distribution of histological types of ovarian tumours

\begin{tabular}{|l|c|c|c|c|}
\hline $\begin{array}{l}\text { Age group } \\
\text { (in years) }\end{array}$ & $\begin{array}{c}\text { Germ cell } \\
\text { tumour } \\
(\mathbf{n})\end{array}$ & $\begin{array}{c}\text { Surface } \\
\text { epithelial } \\
\text { tumour (n) }\end{array}$ & $\begin{array}{c}\text { Sex cord } \\
\text { stromal } \\
\text { tumour (n) }\end{array}$ & $\begin{array}{c}\text { Metasta } \\
\text { tic (n) }\end{array}$ \\
\hline $10-19$ & 13 & 0 & 0 & 0 \\
\hline $20-29$ & 55 & 8 & 3 & 0 \\
\hline $30-39$ & 25 & 17 & 9 & 0 \\
\hline $40-49$ & 12 & 11 & 7 & 0 \\
\hline $50-59$ & 8 & 5 & 2 & 0 \\
\hline $60-69$ & 0 & 10 & 0 & 2 \\
\hline $70-79$ & 0 & 5 & 0 & 1 \\
\hline $80+$ & 0 & 2 & 0 & 1 \\
\hline
\end{tabular}

Among 113 cases of germ cell tumour, most common was mature teratoma accounting for 52 cases $(46 \%)$ followed by dysgerminoma and yolk sac tumour which constituted 30 (26.55\%) and 24 $(21.23 \%)$ cases respectively. Only 5 cases of immature teratoma was seen. Mixed germ cell tumour was rarely seen ( 2 cases). Among 58 cases of surface epithelial tumours serous cystadenocarcinoma was most common (25; $43.2 \%$ ) followed by mucinous cyst adenocarcinoma $(18 ; 31 \%)$. These were followed by endometriod and clear cell carcinoma each accounting for $8(13.8 \%)$ and $6(10.35 \%)$ cases respectively. Among sex cord stromal tumour, granulosa cell tumour was predominant accounting for 15 cases out of 21 (71\%). Fibroma (4) and thecoma (2) are rare finding. Metastatic tumours of the ovary was rare. 4 cases of Krukenberg tumour was identified.

\section{Discussion}

According to this study, the most common ovarian lesions are non-neoplastic, of which the vast majority are functional cyst which are physiological. Similar observation was reported by Maliheh et al. from Iran. ${ }^{[7,8]}$ Furthermore, similar report in Lahore has shown that functional cyst was the most commonly encountered ovarian lesions. ${ }^{[8,9]}$ However, this is at variance with Ashraf et al's report where benign neoplastic tumours was the most commonly encountered ovarian lesions. Also study by Guerriero et al. from Italy showed Endometroma as the most common ovarian mass followed by the functional cyst. $^{[9]}$ Again in another similar study from Netherlands, de Kroon et al., observed that endometroma was the most commonly encountered lesion followed by dermoid cyst and functional cyst. ${ }^{[10]}$

Among the functional cyst in this study, follicular cyst was the most commonly encountered ovarian lesions. This is followed by corpus luteum cyst including haemorrhagic corpus luteum cyst. This finding is similar to studies done by Sumaira et al., from Pakistan who have shown that follicular 
cyst are the most commonly encountered ovarian cyst. ${ }^{[11]}$ Our study is similar to conventional reports where follicular cyst are the most commonly seen cyst in ovary. Nevertheless, other studies of functional cyst contradicts this report. Study by Choi and Kim have shown corpus luteum cyst as the most commonly encountered ovarian lesion. ${ }^{[12]}$ Ashraf et al., also reported similar type of finding. ${ }^{[13]}$ Studies have found that majority of the follicular cysts are asymptomatic and resolved spontaneously. ${ }^{[14,15]}$ The reason for this variation cannot be fully ascertained, but may be attributable to environmental, hormonal and genetic influences.

Other commonly diagnosed cyst in our study included simple/serous cysts. Prevalence of these cyst globally has been supported by few studies. ${ }^{[13,14,15,16]}$ Other functional cyst encountered in this study was relatively rare. This finding is similar to reports of other researchers globally. ${ }^{[14,15]}$

In our study the peak age of incidence for both non-neoplastic and benign neoplastic lesions was seen in the third decade. This is similar to other reports where most of the benign ovarian lesions occur in women of reproductive age groups. ${ }^{[1,17]}$ In our study, ovarian malignancy occurs across all age groups and are seen in reproductive, perimenopausal and postmenopausal women. However, majority of the cases in the western world were seen in elderly postmenopausal women. ${ }^{[18]}$ The rationale for this variation could be attributed to poverty, short life expectancy and ignorance in most developing countries including India.

Using the WHO criteria to classify the ovarian tumours, it is conventionally known that surface epithelial was the most common lesion seen globally. Pilli et al. reported that ovarian surface epithelial tumours accounted for $70.9 \%$ of all ovarian tumours, this is followed by germ cell tumour constituting 21.2\%. Sex cord stromal tumours and metastatic tumour constituted $21.7 \%$ and $6.7 \%$, respectively. ${ }^{[19]}$ In our study germ cell tumour was the most accounted ovarian tumours.
However, surface epithelial tumour was the second most accounted tumour in our locality. This report is similar to reports from Lagos by Onyiaorah et al., where germ cell tumour was the most common ovarian lesion followed by surface epithelial tumours. ${ }^{[20]}$ The reason for this variation can be attributed to short life expectancy in our country. As a result most women do not live long enough into the eighth and ninth decade to present with features of ovarian carcinomas. Also many cases go unreported as they don't seek medical attention.

\section{Conclusion}

In conclusion, functional ovarian cyst were the most commonly encountered ovarian lesions. The follicular cyst followed by the corpus luteum cyst and haemorrhagic cyst were the most commonly encountered functional cyst in the ovary. Majority of this functional cyst occurred in the reproductive age groups. Among the ovarian tumours, germ cell tumours were most commonly seen. This finding is in contrast to common findings where surface epithelial tumours were the most commonly encountered tumours globally.

Thus, in summary, the percentage of ovarian lesions in our study in Jharkhand is as follows:

\begin{tabular}{|l|c|c|}
\hline Type & $\begin{array}{c}\text { Total Number } \\
\text { of cases }(\mathbf{n})\end{array}$ & $\begin{array}{c}\text { Frequency } \\
(\mathbf{\%})\end{array}$ \\
\hline $\begin{array}{l}\text { Non-neoplastic } \\
\text { Lesions }\end{array}$ & 556 & 50.96 \\
\hline $\begin{array}{l}\text { Benign Neoplastic } \\
\text { Tumours }\end{array}$ & 339 & 31.08 \\
\hline Neoplastic Tumours & 196 & 17.96 \\
\hline
\end{tabular}

\section{References}

1. Kayastha S. Study of ovarian tumours in Nepal medical college Teaching Hospital. Nepal Med Coll J 2009;11:200-2.

2. Warner BW, Kuhn JC, Bar LL. Conservative management of large ovarian cysts in children: The value of serial pelvic ultrasonography. Surgery 1992;112:749-55.

3. Choudry A, Bangash N, Malik A, Choudry H. Adolescent ovarian tumours: A Clinicopathological review of 15 cases. J Ayub Med Coll Abottabad 2008;20:18-21. 
4. Pudasaini S, Lakhey M, Hirachad S, Akhter J, Thapa B. A study of ovarian in a tertiary hospital of Kathmandu Valley. Nepal Med Coll J 2011;13:39-41.

5. Merino MJ, Jaffe G. Age contrast in ovarian malignancy pathology. Cancer 1993;15:53744.

6. Malik IA. A prospective study of clinicpathological features of epithelial ovarian cancer in Pakistan. J Pak Med Assoc 2002;52:155-8.

7. Wasim $\mathrm{T}$, Majrroh A, Saddiq $\mathrm{S}$. Comparison of clinical presentation of benign and malignant ovarian tumours. J Pak Med Assoc 2009;59:18-21.

8. Maliheh A, Mohammed $\mathrm{H}$, Nadereh $\mathrm{M}$, Mehdi Y, Fazareh G, Mojgan E. Surgical histopathology of benign ovarian cysts: A multicentre study. Iran J Pathol 2010;5:1326.

9. Guerriero S, Alcazar JL, Pascual MA, Ajossa S, Gerado M, Bargellini R, et al. Diagnosis of the most frequent benign ovarian cysts: Is ultrasonography accurate and reproducible? J Womens Health (Larchmt) 2009;18:519-27.

10. de Kroon $C D$, van der Sandt HA, van Houwelingen JC, Jansen FW. Sonographic assessment of non-malignant ovarian cysts: Does sonohistology exist? Hum Reprod 2004;19:2138-43.

11. Yasmin $\mathrm{S}$, Yasmin A, Asif $\mathrm{M}$. Clinicohistological pattern of ovarian tumours in Peshawar region. J Ayub Med Coll Abbottabad 2008;20:11-3.

12. Choi HJ, Kim SH, Kim SH, Kim HC, Park $\mathrm{CM}$, Lee HJ, et al. Ruptured corpus luteal cysts: CT Findings. Korean J Radiol 2003;4:42-5.

13. Ashraf A, Shaikh AS, Ishfaq A, Akram A, Kamal F, Ahmad N. The relative frequency and histopathological patterns of ovarian masses. Biomed 2012;28:98-102.
14. Mackenna A, Fabres C, Alam V, Morales V. Clinical managementof functional ovarian cysts: A prospective and randomized study. Hum Reprod 2000;15:2567-9.

15. Stenchever MA, Droegemueller W, Herbst AL, Mishell DR Jr. Comprehensive. Gynecology. 4th edition. St. Louis, MO: Mosby; 2006: p. 901-10.

16. Barel O, Smorgick N, Pansky M, Schneider D, Halperin R. Clinical and laboratory presentation of haemorrhagic corpus luteum. J Gynaecol Surg 2008;24:11-6.

17. Mendal SK, Banyopadhyay R, Nag DR, Roychowdhury S, Mondal PK, Sinha SK. Histologic pattern, bilaterality and clinical evaluation of 957 ovarian neoplasms: A 10year study of a tertiary hospital of eastern India. J Cancer Res Ther 2011;7:433-7.

18. Quirk JT, Natarajan N. Ovarian cancer incidence in the United States, 1992-1999. Gynaecol Oncol 2005;97:519-23.

19. 19. Pilli GS, Suneeta KP, Dhaded AV, Yenni VV. Ovarian tumours: A study of 282 cases. J Indian Med Assoc 2002;100:420, 423-4, 447.

20. Onyiaorah IV, Anunobi CC, Banjo AA, Fatima AA, Nwankwo KC. Histopathological patterns of ovarian tumours seen in Lagos University Teaching Hospital: A ten year retrospective study. Nig Q J Hosp Med 2011;21:114-8. 